\title{
Hematoksilen-Eozin'den Moleküler Tekniklere: Patolojinin Tarihçesine Kısa Bir Bakış
}

\author{
From Hematoxylin\&Eosin to Molecular Techniques: \\ A Short Overview of the History of Pathology
}

Kutsal YÖRÜKOĞLU

Dokuz Eylül Üniversitesi Tip Fakültesi, Patoloji Anabilim Dalı, INCIRALTI, IZMIR

\section{ÖZET}

Formalin ile tespit edilmiş, parafine gömülmüş dokulardan elde edilen ve hematoksilen eozin ile boyanmış kesitlerin mikroskopik değerlendirmesi, günlük pratiğimizin vazgeçilmezidir. Bu pratik nasıl gelişmişs? Günümüzün patolojisi nasıl gelişmiş, evrilmiş? Bu pratiğin uygulanmasında parafin infiltrasyonu, boyama gibi yöntemler, kesit almak için mikrotom, değerlendirmek için mikroskop gibi cihazlar kullanıyoruz. Bu yöntemler nasıl geliştirilmiş, cihazlar ne zaman ve nasıl yapılmış? Vazgeçemediğimiz Hematoksilen-Eozin boyasını kim, ne zaman, nasıl bulmuştur? Bu derlemede, günlük koşturmaca içerisinde fazla düşünmediğimiz, farkında olmadığımız, ama bu koşturmacayı sağlayan cihazların, yöntemlerin, tekniklerin, boyaların nasıl geliştiğine kısaca değinilmeye çalışılmaktadır.

Anahtar Sözcükler: Patoloji, Tarihçe, Hematoksilen, Eozin

\section{ABSTRACT}

Microscopical interpretation of sections taken from formalin fixed and parafin embedded tissue is our daily practice. How is this practice developed? How is today's pathology develop and evolved? This practice needs implementation of procedures such as paraffin infiltration and staining, and devices such as microtome and microscope. How and when are these methods and devices are developed? Who have invented indispensible Hematoxylin \& Eosin staining method? This review traces the evolution of pathology and the necessary devices and techniques, that we need but not aware of, for this daily rush.

Key Words: Pathology, History, Hematoxylin, Eosin

\section{GİRIŞ}

Einstein 18 Nisan 1955 yllında New Jersey'de yaşama veda eder ve vasiyeti gereği otopsi sonrası bedeni yakılır ve külleri bilinmeyen bir yere gömülür. Aynı tarihte Princeton Üniversitesi'nde tarihin en büyük hırsızlığı gerçekleştirilir. Patolog Thomas Harvey, otopsi sırasında Einstein'in beynini çalar ve 240 parça olarak saklamayı başarır. Normal beyin parietal operculum diye tanımlanan bir sulkus ve matematiksel ve görsel değerlendirmeyi sağlayan inferior parietal lobu içerir. Einstein'm beyninde parietal operculum olmadığı gözlenir. Bu, inferior parietal lobun \%15 daha fazla büyümesini sağlamıştır. Bugün Einstein'ın beyni 46 kesit halinde herkesin çalışmasına açıktır.

(J Curr Pathol 2017, 1:1-7)

Geliş Tarihi : 14.06.2014 Kabul Tarihi : 15.06.2014
$\mathrm{Bu}$ hırsızlık olayına gelene kadar ve sonrasında patologlar bilimin neresinde yer almışlardır? Patoloji nasıl gelişmiş ve evrilmiştir? Vazgeçemediğimiz Hematoksilen-Eozin boyasını kim, ne zaman, nasıl bulmuştur? Önce patolojinin gelişimine göz atıp, sonra yöntem ve cihazlara bakacağız.

\section{PATOLOJINININ GELISSIIMI}

Patolojinin başlangıcı Mısır'da hastalıkların dökümante edilmesi ile 3.500 yıl önce başladı diyebiliriz. Eski Yunan'da Hipokrat ve Aristo, Romalılarda Celsus ve Galen, Bizanslarda Aetius ve Arap dünyasinda İbn-i Sina ve İbn-i Zühr tıp biliminin gelişimine önemli katkılar sağlamışlardır (1).

Modern patoloji Rönesans döneminin anatomisinden doğmuştur. Antonio Benivieni hastalıkların nedenini ve

\section{İletişim: Kutsal YÖRÜKOĞLU}

Dokuz Eylül Üniversitesi Tip Fakültesi,

Patoloji Anabilim Dal, INCIRALTI, IZMIR

E-posta: kutsal.yorukoglu@deu.edu.tr Tel: +90 2324123410 
hastaların semptomlarını anlamak için otopsi yapar. 20 otopsi ile sinırl gözlemlerini 1507'de De Abditis Morborum Causis (Hastalıkların Gizli Nedenleri) adlı kitapta yayınlar. Benivieni'nin otopsi tekniğinin bugünkü protokoller ile benzer olduğu vurgulanır. 1543'de Fransız Jean Fernel fizyoloji ve patoloji terimlerini kullanır. Yine 1543'te Andreas Vesalius ilk modern anatomi kitabını (De Humani Corporis Fabrica) yayınlar. Patoloji terimini ilk kullanan ise Medicina adlı kitabinda Jean Francois Fernel'dir (1). Epey sonra GB Morgagni 700 otopsinin bulgularını 1769'da yayınlayarak hastalıkların anatomik temellerine inen kişi olur (2) (Şekil 1).

Patolojinin gelişiminde ve bugüne gelinmesindeki basamak taşları mikroskopun gelişimi, tespit solüsyonları, mikrotomun geliştirilmesi, doku gömme yöntemi, boyama, frozen kesit, otomasyon, elektron mikroskopi, histokimya, polarize ve floresan mikroskopi, immünohistokimya ve moleküler patoloji olarak özetlenebilir.

\section{MİKROSKOP}

Optik konusunda ilk iki kitap 13. yüzyllda Pecham ve Witelo (Perspectiva) tarafından yazılmıştır. Bu kitaplarda görme

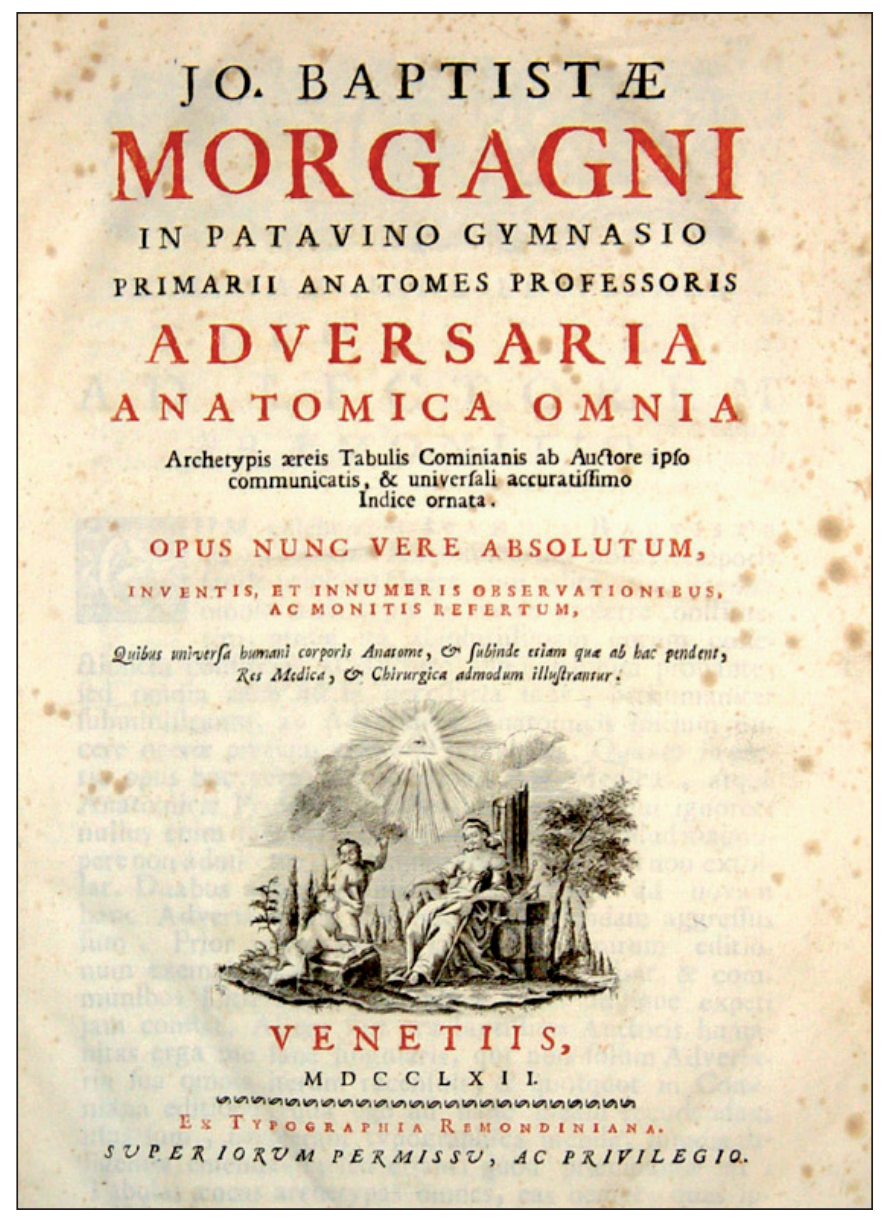

Şekil 1: Morgagni'nin 700 otopsinin bulgularını yayınladığı kitabının kapağl. konusu ve kırılma gibi olaylar incelenmiștir. 16. yüzyılda Maurolico tarafindan yazılan Photismi de lumine gölge, yansıma, gökkuşağı, gözün yapısı, gözlükler ve bunların görme kusurlarını düzeltme şekli ile ilgili ve Rönesans'ın en iyi optik kitabı kabul edilir. Photismi de lumine kitabının basımı geciktiği için ve bu arada teleskop bulunduğu için etkisi fazla olmaz. 16. Yüzyılda Giambattista della Porta 2 optik kitabı yazar. Porta'nın bir başka kitabı da Magia Naturalis'dir. Doğal büyü anlamına gelen bu kitabın optik bölümünde Porta, içbükey ve dışbükey aynaları, mercekleri, uzağı görmeyi sağlayan gözlükleri incelemektedir. Içbükey ve dışbükey merceklerle çok uzak ve çok yakındaki cisimlerin daha iyi görülebileceğini açılklar. Bu açıklamalara dayanarak Porta'nın teleskop ve mikroskopun ilkelerine ulaşmıs olabileceği söylenmektedir. Gerçekten de Porta daha sonra yazdığı De Refractione (Kırılma) adlı kitabında içbükey ve dışbükey merceklerle yaptığı deneyleri anlatmaktadır (3).

Mikroskop büyük olasilıkla teleskoptan sonra icat edilmiștir. Mercekler 13. yüzyılda biliniyordu. Ilk kompozit mikroskop 159l'de Zacharias Jansen tarafindan yapilır (4). Bu mikroskoplarda sferik ve kromatik sapma sorunları vardı ve materyalden yansıyan ışık aracıllğı ile görüntü sağlanıyordu. Bu sorunların aşılması 17. yüzyılda Anton von Leeuwenhoek sayesinde oldu ve ilk tek lensli mikroskopunu 1673'te yaptı (Sekil 2). Leeuwenhoek mercekleri yontup parlatarak çok küçük ve kaliteli mercekler elde etti. Tek mercek ile yapılan mikroskoplarda büyütme sınırlı olup, kromatik sapma görüntü kirliliğine yol açıyordu ve Leeuwenhoek'un yaptığı bu mikroskoplar tek kullanımlık idi (4). Akromatik lenslerin elde edilmesi ise ancak 19. yüzyılda gerçekleşebilmiştir (3).

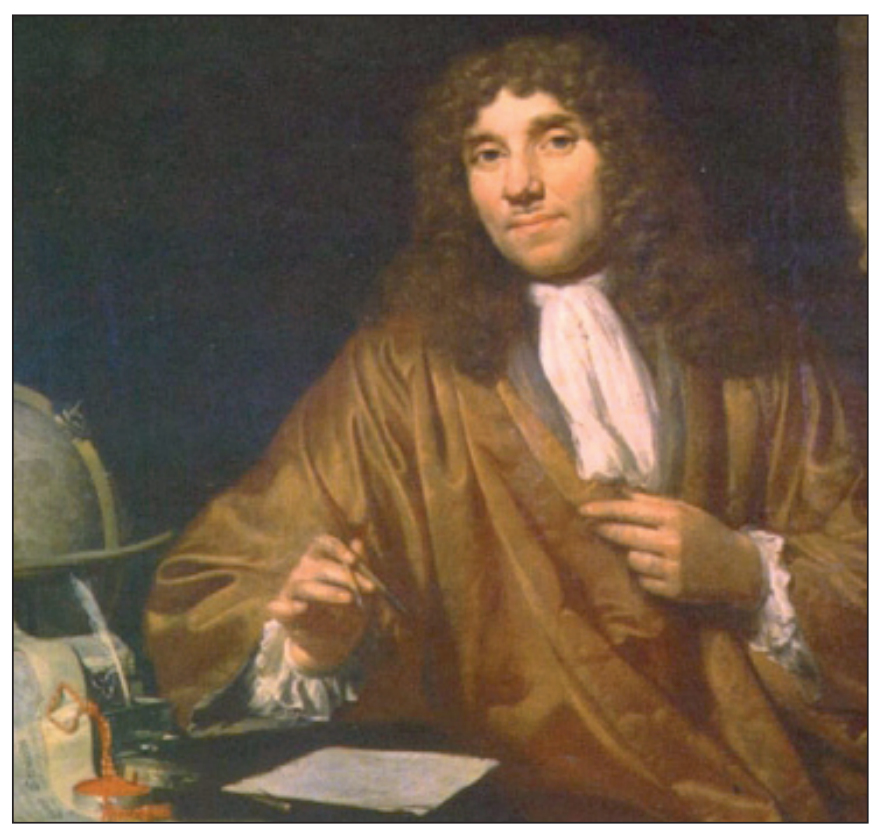

Şekil 2: Mikroskopun gelişiminde en önemli isimlerden birisi Anton von Leeuwenhoek. 
17. yüzyılda mikroskopu ilk kullananlar Robert Hooke, Jan Swammerdam, Marcello Malpighi, Nehemiah Grew ve Anton von Leeuwenhoek olmuştur. Hooke Micrographia ile ilk mikroskopi kitabını yayınlamıştır. Bu kitapta ilk defa hücre terimini ölü mantar hücreleri için kullanmıştır. Swammerdam, mikroskop altında ilk diseksiyonu yapan kişi olmuş, daha çok böcekler üzerinde çalışmış ve bu konuda iki kitap yayınlamıs. Malpighi (1628-1694) ise mikroskobik anatominin kurucusu, modern histoloji ve embriyolojinin öncüsü Italyan hekim olarak tanımlanır. Malpighi, hem tıp araştırmalarında hem de civciv embriyosunu incelemek için mikroskopu kullanmış ancak nasıl bir mikroskop
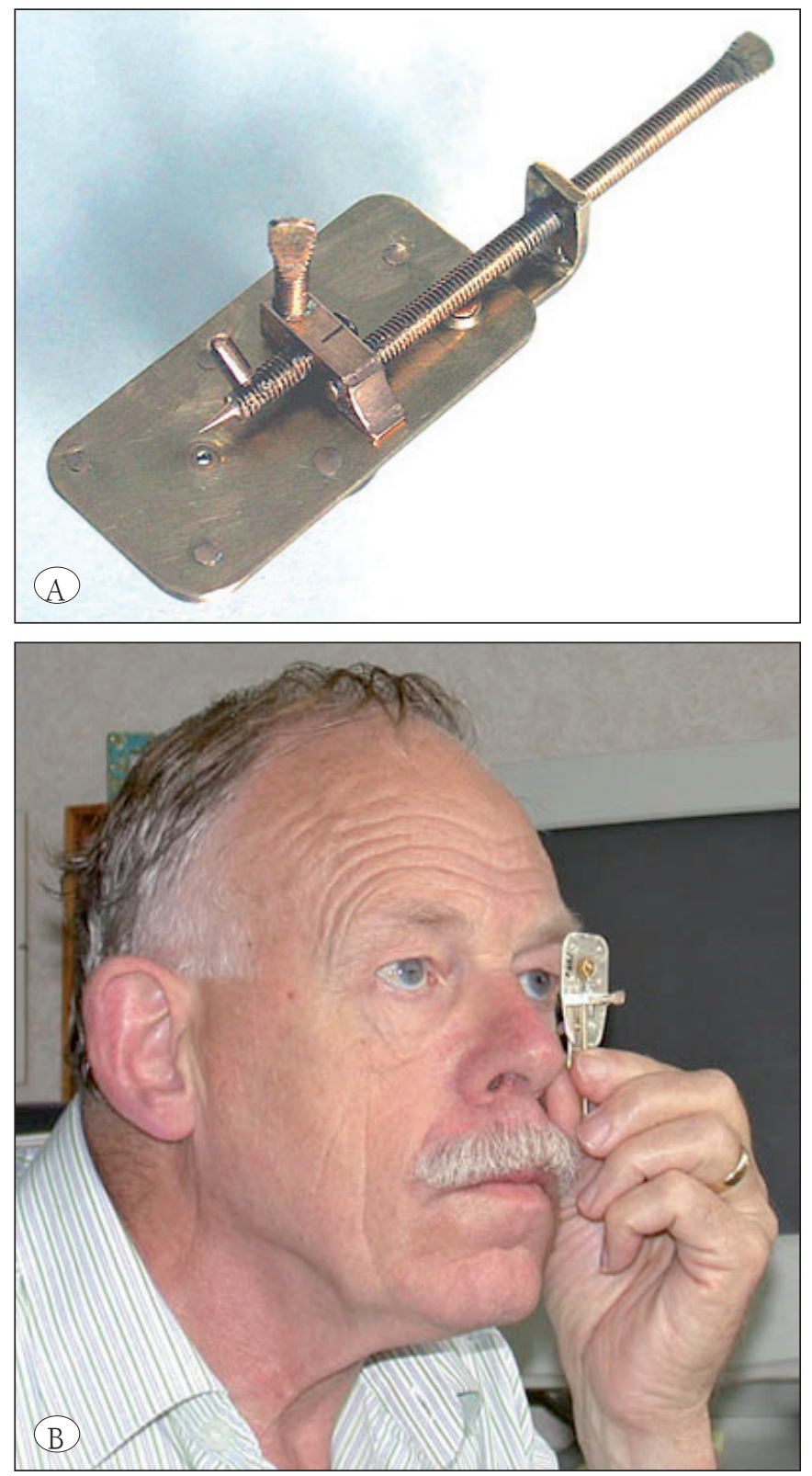

Şekil 3: A) Anton von Leeuwenhoek'un geliştirdiği mikroskop ve B) bu mikroskopun kullanımının ne kadar zor olduğu görülüyor. kullandığını bilmiyoruz. Organların çeşitli dokulardan, bu dokuların da çıplak gözle görülmeyen, değişik biçimlerde yapılardan oluştuğunu gözlemlemiş. Malpighi doku çeşitlerini incelerken kılcal damarları keşfetmiş. Mikroskopun gelişimi ve kullanımında Leeuwenhoek'un yeri ise ayrıdır. Yaptı̆̆ı tek mercekli mikroskop ile 270 defa büyütme gücü elde etmiştir ve bu mikroskopların NA=0.4 olduğunu vurgulamak gerekir (4). Bu 1.5 mikronluk bir ayrıntı anlamına gelmektedir. Yaptığı mikroskopların küçük olması, göze yakın tutulması gerekliliği ve incelenecek örneğin merceğe çok yakın bir tutucuya tutturulması, kullanımının zorluğuna yol açmaktadır (Şekil 3A, B). Leeuwenhoek'un daha iyi mikroskoplar yaptığl, hatta günümüz kalitesinde görüntü elde edilebilen kaliteye ulaştı̆̆ da iddia edilmektedir. Bu tek mercekli mikroskoplarının en önemli özelliği kromatik sapmalarının çok küçük olmasıdır. Leeuwenhoek incelemelerinde Malpighi'nin bulgularını doğrulamış, eritrositleri tanımlamış, nükleusu ve spermatozoitleri gözlemlemiştir. Bakteriler üzerine ilk gözlem yine Leeuwenhoek'a aittir ve bunun için karanlık alan mikroskopi tekniğini kullandığı sanılmaktadır (4). Leeuwenhoek'un tekniğini kullanan ve devam ettiren olmadığ1 için mikroskopide gelişmeler akromatik bileşik mikroskopun bulunacağı 1830'lardan sonra olabilmiştir (3).

Hücrenin tanımlanmasından sonra 1700'lerin sonlarında Marie Francois Xavier Bichat öncülüğünde organlar ve dokular tanımlanır. 1827 yılında Joseph Lister sferik ve kromatik sapmayı düzelterek kompozit mikroskopun gelişimine önemli katkı sağlar. Ernst Abbe ve Carl Zeiss'ın çalışmaları ile 1830'larda Amici ve Chevalier akromatik lensleri geliştirirler ve akromatik mikroskoplarda fiziki sınır olan 0.5 mikronluk diskriminasyon sınırına ulaşılır (Şekil 4A, B). Akromatik mikroskopun kullanıma girmesi ile hücre teorisinin ana fikirleri Matthias Schleiden ve Theodor Schwann tarafindan ele alınmıştır. Gerçek anlamda hücre teorisinin geliştirilmesi ise Rudolph Virchow ve Claude Bernard tarafindan gerçekleştirilmiştir. Virchow 1858'de Die Cellularpathologie kitabında hücrelerin, dokuların, organların, sistemlerin ve bireylerin temel yapıtaşı olduğunu tanımlamıştır. Hücrenin temel fonksiyonel birim olduğunu Claude Bernard kanıtlamıştır (3). Histopatolojinin doğuşu 1838 yılında Johannes Müller'in yazdiğı On the Nature and Structure Characteristics of Cancer (Ueber den feineren Bau der krankhaften Geschwülste) isimli ilk histopatoloji kitabı olarak kabul edilebilir (4). 1845'de Hermann Lebert sıvılardaki hücrelerin incelenmesi ile benignmalign ayırımının yapılabileceğini, malign hücrelerin daha büyük nükleusa sahip olduğunu söyler (4). Ancak, boyama yöntemi olmadığı için bu bulgular fazla dikkate alınmaz. Yine 1850'lerde Thomas Hodgkin, mikroskopun ileride önemli keşifler sağlayacağı kehanetinde bulunur (1). 1870'lerde Ernst Abbe Zeiss fabrikasinda apokromatik ve immersiyon lensleri geliştirerek mikroskop kalitesini yükseltir. Ilk binoküler mikroskop 1902 yılında yapılır (4). 
Dokuları daha ince kesebilmek için sertleștirmek gerektiği çok öncelerde fark edilmiş. Malpighi, dokuları sertleştirmek için kaynatmış, yani pişirme yöntemini uygulamıştır. Diğerleri alkol, asetik asit, potasyum dikromat gibi maddeleri kullanarak sertleștirme yanında canlı haline yakın biçimde kalmalarını sağlamaya çalışmışlardır. Bu dönemlerde kesit almak için jilet veya bistüri kullanılmıştır. Daha sonra birden fazla madde içeren bileşik tespit solüsyonları kullanıma girmeye başlar. Müller solüsyonu 1860, Zenker solüsyonu 1894, Carnoy fikzatifi 1887'de tanımlanır. Formalin'in keşfi ise Ferdinand Blum tarafindan 1893 yilında olur (4).

Dokular önceleri ustura ile örneklendikten sonra yine ustura ile kesit alınmış. Daha sonraları dokuları tutan ve böylece daha ince kesit alınmasını sağlayan aletler geliştirilmiş. Ilk el mikrotomu sürgünleri kesmek amacı ile 1770'de Hill tarafından yapılmıs. Daha sonra hem dokuyu tutmak için hem de vida ayarlaması ile ince kesit almayı sağlayan aletler geliştirilmiş. Ilk mikrotom kullanımı aslında botanikte olmuş. Hayvan dokularında mikrotom kullanımı ancak 1848 yılında Topping'in mikrotomu ile olmuş (4). Bu tarihten sonra değişik mikrotomlar yapılmış ama asıl gelişmeyi sağlayan Charles Darwin'in oğlu Horace Darwin'in 1885'de geliştirdiği Cambridge rocker ile sağlanmıştır. Bu mikrotomda bıçak sabitlenmiş ve bloktan vertikal hareket ile kesitler alınabilmiş. 1886 'da da ilk rotary mikrotom yapılmıs. Kızaklı mikrotom ise 1910'da Jung tarafından geliştirilmiştir. Parafin gömme yöntemini kimin bulduğu ise açık değildir. 1869'da Klebs, 1871'de Born ve Stickler, 1881'de Giesbrecht, 1881'de Butschli'nin adları geçiyor. Önce dokunun etrafına parafin eklenmiş, daha sonra dehidrasyon ve parafin infltrasyonu geliştirilmiş (4). Yöntemin oturması, ilk patologların görevlendirilmesi ile Mayo Kliniği'nde gerçekleşmiştir.

\section{BOYAMA}

Leeuwenhoek döneminde dokuları boyamak için bu erken histologlar kök boyası, safran, indigo gibi maddeleri kullanmışlar ve dokuları korumak için değişik kimyasallar kullanmışlardır (5). 1858 yılına kadar böyle giderken, bu tarihte Joseph von Gerlach serebellumu amonyaklı carmine ile başarıyla boyamıştır (5). Virchow çoğunlukla carmine kullanmıştır. Günümüzde de hematoxylin en yaygın kullanılan doğal boyadır. Haemotoxylon campechianum Orta Amerika'da yetişen bir ağaçtır (Şekil 5A-C).

Hematoxylin, doğal ortamda koyu kırmızı renkte olduğu ve ağaçtan elde edildiği için Yunanca kan anlamına gelen Haimato ve ağaç anlamına gelen Xylon sözcüklerinden türetilmiştir. Hematoxylin (C.I. 75290) Güney Amerika bölgesinde yetişen Bakkam ağacının (Haematoxylon campechianum) kaynatılması ve kristalleştirilmesi ile elde edilir. Ticari olarak bazı maddeler ile karışmıs olarak satılır. Suda erir (1g/100 $\mathrm{ml}$ ) ama alkolde daha fazla erir (30-40 g/100 ml). Aktif boya okside formu olan hematein'dir. Modern dönemlerden önce
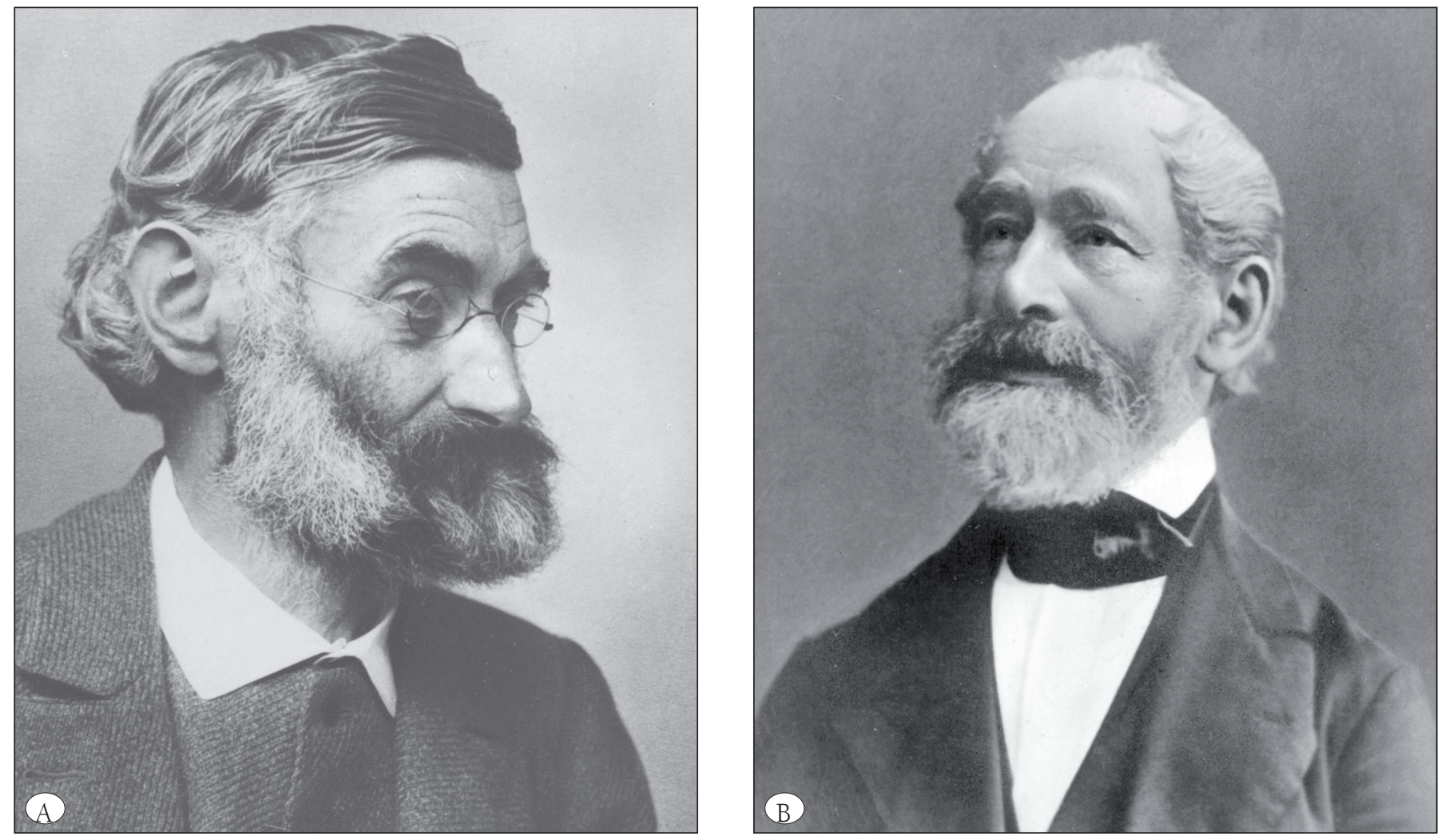

Şekil 4: Günümüz mikroskoplarının gelişimini sağlayan A) Ernst Abbe ve B) Carl Zeiss. 

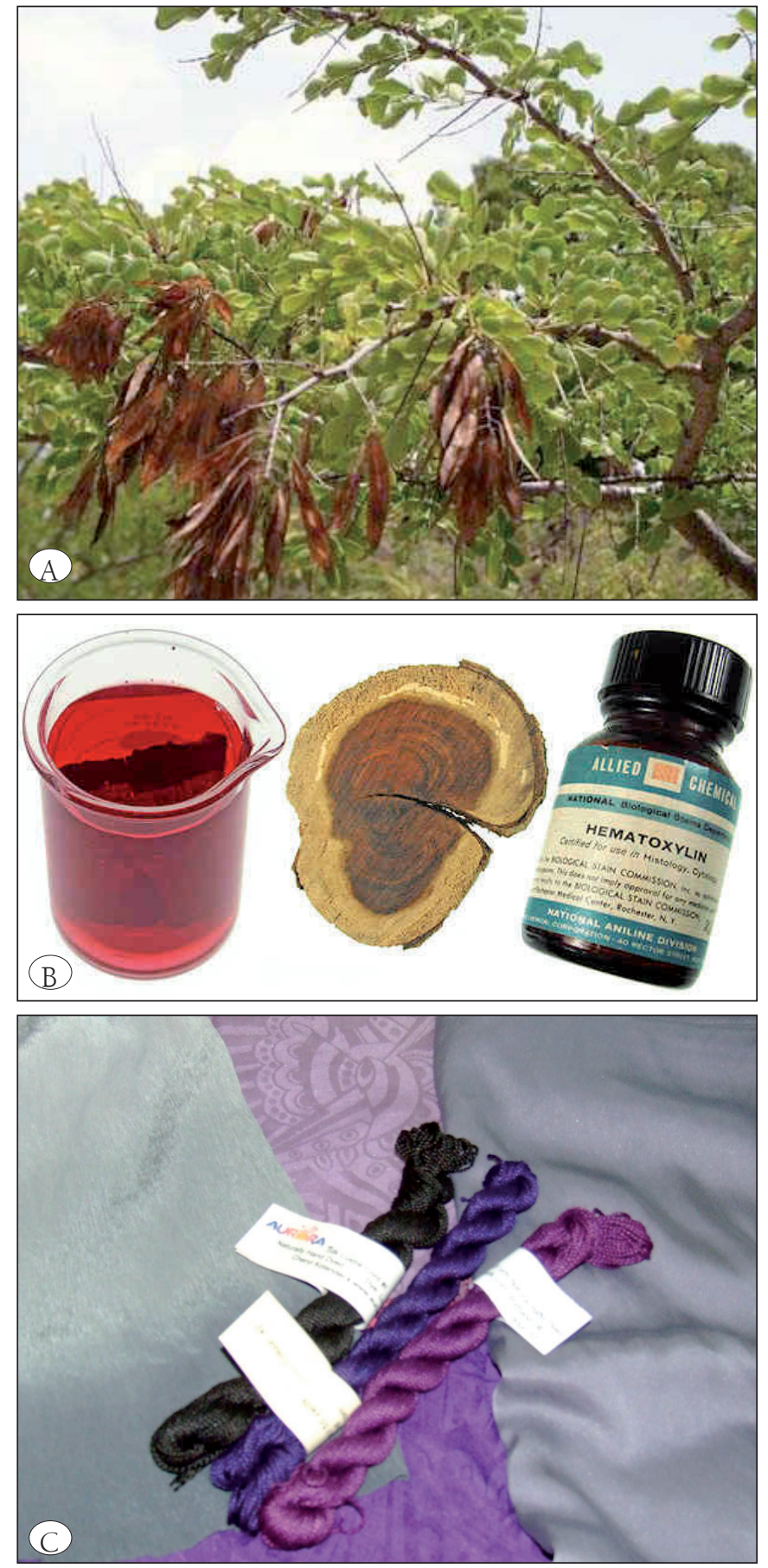

Şekil 5: Hematoksilenin elde edildiği A) Bakkam ağacı, B) ağacın kesiti ve solüsyonun rengi, $\mathrm{C}$ ) hematoksilen ile elde edilebilen renkler.

oksidasyon işlemi için pamukla karıştırılır, hava ve güneşe 6 hafta veya daha uzun süre tutularak sağlanırdı. Daha sonra sodyum iodat ve civa oksit kullanılarak oksidasyonu sağlandı. Burada oksidasyon hemen başlamaz ve zamanla gelişir. $\mathrm{Bu}$ sırada gliserin eklenmesi aşırı oksitlenmeyi ve mantar üremesini önler. Saf olarak zaylf bir boyadır ama metal tuzları (mordant) ile birleştirildiğinde iyi bir nükleus boyası haline gelir. Ayrıca dokularda metali göstermek, myelini, mitozu, fibrini, kas çizgilenmelerini ve bazı doku elemanlarını boyamada da kullanılır. Metaller ile birleştiğinde farklı renk boya oluşur. Ammonyum şapı (aluminum ammonium sulfate) ile birleștiğinde asit solüsyonda pembe-mor, alkali ise mavi renktedir. Potasyum şapı (aluminum potassium sulphate) veya sodyum şapı (aluminum sodium sulphate) da kullanılabilir. Demir ve krom ile mavi-siyah, bakır ile maviyeşil, kalay ile kırmızı, kurşun ile koyu kahverengi, osmium ile yeşil-kahve renk alır. Şaplı hematoksilen ile nükleusun boyanması asetik asit kullanılarak artırılabilir. Şaplı hematoksilenlerde regresif boyamada doku önce aşırı boyanır, sonra istenen düzeye gelene kadar soldurme (diferansiasyon) işleminden geçirilir. Progresif boyamada ise istenen boyanma şiddetine gelene kadar kontrol edilerek tutulur. Progresif hematoksilenler daha az konsantredir ve yavaş boyarlar. Regresif hematoksilenler konsantredir ve hızlı etki ederler. Regresif hematoksilen kullanıldığında zamandan kazanılır ve jelatin gibi lam üzerindeki fazlalıklar da uzaklaştırılarak daha temiz bir boyanma elde edilir. Diferansiasyon seyreltilmiş asit (asit alkol) ile yapılır ve işlem suda yıkayarak sonlandırılır. Progresif ve regresif hematoksilenler ile elde edilen sonuç (boyanma) aynıdır. Tüm şaplı hematoksilenler asit olduğu için nükleuslar pembemsi boyanır. Kontrast elde etmek için renklerini maviye dönüştürmek gerekir. Bunun için amonyakh su veya sodyum karbonatlı suya batırılır veya çeşme suyunda 2-5 dakika yıkanır (6).

Hematoxylin saf haliyle iyi boyamaz ve bazı otörler boya olarak kabul etmez. Okside olduğunda hematein' dönüşür ve bir mordant ile birleştirildiğinde dokuyu koyu maviden siyaha kadar bir renge boyar. Hematein hali amfoteriktir ve asit pH'da kırmızı, bazik pH'da ise mavidir (7).

Yerlilerin kullandığı bu doğal boyayı 1502'de Ispanyol gezginler Meksika eyaleti olan Campeche'de keşfetmişler ve Avrupa'ya getirmişlerdir (7). Bakkam ağacı'ndan elde edilen hematoksilen 1520'li yıllarda boya olarak kullanılmaya başlanmış ve sonrasında tekstil sanayinin en önemli maddesi haline gelmiştir. Robert Hooke hematoksileni sıviları renklendirmek için kullanmıştır (8). Quekett hayvan dokularını boyamak için tanımlamış ama ayrıntılı olarak tarif eden 1863'de Wilhelm von Waldeyer olmuş $(4,5,7,9)$, doğrudan suda eriterek nöronları boyamaya çalışmıştır. 1865 yılında ise Bohmer mordant kullanarak dokuları hematoksilen ile başarıyla boyamıştır.

Eosin ise katrandan elde edilen sentetik turuncu-pembe renkli bir boyadır. Eosin sözcüğü Yunanca şafak ve şafak tanrısından gelmektedir. Eosin Y floreseinin tetrabromo, Eosin B ise dibromo dinitro türevidir. Eosin Y hafif sarı renkte, Eosin B ise mavimsi renktedir. Eosinin tetrabromofloresceinin potasyum tuzu hali 1871 'de Baeyer ve Caro tarafından sentezlenmiştir. Baeyer ve Caro'nun aromatik bileşikler üzerine yaptıkları 
tanımlamalar sonrası phthalein boyaları geliștirilmiștir ve eosin bunlardan ilkidir. AGFA'nın kurucularından olan Martius BASF eosin ürünü satın almış ve kömür katranı hidrokarbon naftalinden elde edilen Eosin'in formülünü ve elde ediliş yöntemini tanımlayarak sırrı ortadan kaldırmıştır. Bu diğer azo boyalarının (alizarin red, Congo red, v.b.) bulunmasının da önünü açacak, Eosin'in kullanımını yaygınlaştıracaktır (10). Eosin ilk defa 1876'da Dreschfeld ve Fischer tarafindan doku boyası olarak kullanılmış ve tanımlanmışır. Yine aynı tarihte Wissowzky hematoksilen ve eosini birlikte kullanan ilk kişi olmuştur $(4,5)$. Hemen sonrasında 1878'de Busch hematoksilen ve eosini beraber kullanmıs ve tanımlamıştır (9). Histopatolojik boyamalarda bir başka dönüm noktası ise 1855'de 17 yaşındaki William Perkin'in anilin boyalarının bulması olmuştur. Anilin boyalarının gelişmesi ile histopatolojik boyamalar da hızla gelişmiştir (5).

Ebegümeci familyasından olan ve tropikal ülkelerde yetişen Kerkede çiçeğinin histopatolojide progresif bir boya olarak kullanılabileceği bildirilmiştir. Hibiscus sabdariffa L.'nin kurutulmuş dalları tropikal ülkelerde gıda boyamada, çay yapımında kullanılmaktadır. Çiçeğin sıcak suda elde edilen özüne demir klorid ve asetik asit eklenerek hücre nükleusunu maviye boyayan ve hematoksilene benzer sonuç veren bir boya elde edilmektedir (11). Bu boyanın hematoksilen kadar iyi sonuç verdiği, solmadığı bildirilmiștir. Ama hâlâ hematoksilen ve eozin, histolojinin vazgeçilmez boyama yöntemi özelliğini korumaktadır.

\section{CİHAZLAR}

19.yüzyılın sonlarında büyük tıp merkezleri cerrahi patoloji materyalini değerlendirmeleri için tam zamanlı patolog çalıştırmaya başlamışlardır. New York'daki Bellevue Hastanesi ilk patologunu (William HenryWelch) 1878'de görevlendirmiş, Mayo Kliniği ise 1904'de ilk cerrahi patolog ile sözleşme yapmıştır. Bu ilk patologlar 1870'lerde intraoperatif frozen kesiti geliştirmişler ve histopatolojik bazı boyaları bu sisteme uyarlamışlardır. Parafin infiltrasyonu da bu tarihlerde Edward Klebs tarafından geliştirilmiştir $(1,5)$. Formaldehid ile doku tespiti 1893 yılında Ferdinand Blum tarafından tanımlanmıştır (1). 1870'lerde Cal Ruge isimli Alman jinekolog mikroskopta serviks ve endometrium kanseri tanısı koyar ve uluslararası konsültasyon alan ilk hekim olur. 1890'larda meme cerrahisi sırasında frozen değerlendirme yapılır. 194l'de ise Albert Coons ve arkadaşları antikoru floresan boya ile birleștirerek immünohistokimyanın temellerini atarlar (1). Virchow ile çalışan David Paul von Hansemann anaplazi terimini kullanır. Deniz kestanesi yumurtaları ile çalışan Theodor Boveri 1914'de zur Frage der Entstehung maligner Tumoren kitabında kanser biyolojisi ile ilgili 20 hipotez ile genetik temeli olabileceğini vurgular. Bu hipotezler 100 yll sonra kanser kromozomları çalışıldığında ispatlanabilir.

\section{MOLEKÜLER TEKNİKLER ve SONUÇ}

Moleküler çağa geçiş, bu gelişmelerden daha hızlı olmuştur. 1953'de DNA çift sarmal yapısı, 1969'da FISH tanımlanır. 1980'lerde Kaliforniyada Cetus Corporation'da Kary Mullis önderliğinde PCR tekniği geliştirilir (1). 1970 ve 80'lerde serviks ve over kanserlerinin değerlendirilmesinde DNA görüntülemesi ve akım sitometrisi kullanılır (12-14). 1990'ların başlarında kromozom rearrangement çalışılmaya başlanır. PCR ile taze ve parafine gömülü dokularda $\mathrm{LOH}$ çalışılmaya başlanır. Moleküler tanısal uygulama ilk defa 1992'de T-hücreli lenfomalarda Southern blotting yöntemi ile klonalite çalışmasıdır (1). 1996'da ilk otomatize DNA sekanslama cihazı üretilir. 2003'de doku mikroarray yöntemi $(15,16)$, sonra da mikroarray gen ekspresyon teknolojisi (17) geliştirilir. 2014'e geldiğimizde moleküler tanısal test sayısı 3.000'in üzerine çlkmıştır.

\section{KAYNAKLAR}

1. Eijk, Ronald van. Technological advances in molecular pathology: a journey into the archives dissertation. The handle at http://hdl. handle.net/1887/20866. Issue Date: 2013-05-08

2. The Emergence of Pathology. http://nfs.unipv.it/nfs/minf/ dispense/patgen/lectures/files/history.html

3. Ronan CA. Bilim Tarihi. Dünya kültürlerinde bilimin tarihi ve gelişmesi. TÜBITAK Yayınları, Ankara, 2003. s:354-355, 417, 437-439, 476-478.

4. Titford M. A short history of histopathology technique. J Histotechnol 2006; 29: 99-110. http:// histopathologyresearchresources.blogspot.com/2009/05/shorthistory-of-histopathology.html

5. Titford M. Progress in the development of microscopical techniques for diagnostic pathology. J Histotechnol. 2009; 32: 9-19.

6. Millikin PD. Hematoxylin Staining, Some Technical Notes. http:// stainsfile.info/StainsFile/stain/hematoxylin/hxintro.htm

7. Titford M. The long history of hematoxylin. Biotech Histochem. 2005; 80:73-8. PMID:16195172

8. Nuclear and cytoplasmic stains. In: Sheehan DC, Hrapchak BB, editors. Theory and practice of histotechnology. The C.V.Mosby Company, St.Louis, 1980.137-158.

9. King DF, King LAC. A brief historical note on staining by hematoxylin and eosin. Am J Dermatopathol. 1986; 8:168. PMID: 2424331

10. Morris PJT, Travis AS. A History of the International Dyestuff Industry. American Dyestuff Reporter, Vol. 81, No. 11, November 1992. http://colorantshistory.org/ HistoryInternationalDyeIndustryRev $1 /$ HistoryInternational DyestuffIndustryFirefox/dyestuffs.html

11. Solomon AB. Iron-Roselle: A Progressive Nuclear Stain Substitute For Haematoxylin. J Histotechnology 2008; 31:57-9. DOI: http:// dx.doi.org/10.1179/his.2008.31.2.57 
12. Rodenburg CJ, Ploem-Zaaijer JJ, Cornelisse CJ, Mesker WE, Hermans J, Heintz PA, Ploem JS, Fleuren GJ. Use of DNA image cytometry in addition to flow cytometry for the study of patients with advanced ovarian cancer. Cancer Res. 1987; 47: 3938-41. PMID: 3607741

13. Smeulders AW, Cornelisse CJ, Vossepoel AM, Ploem JS. An image segmentation approach to the analysis of nuclear texture of cervical cells. Acta Histochem Suppl. 1979; 20: 217-22. PMID: 122372

14. Cornelisse CJ, Ploem JS. A new type of two-color fluorcscence staining for cytology specimens. J Histochem Cytochem. 1976; 24: 72-81. PMID: 56393

15. Kononen J, Bubendorf L, Kallioniemi A, Barlund M, Schraml P, Leighton S, Torhorst J, Mihatsch MJ, Sauter G, Kallioniemi OP. Tissue microarrays for high-throughput molecular profiling of tumor specimens. Nat Med. 1998; 4: 844-7. PMID: 9662379
16. Hendriks Y, Franken P, Dierssen JW, de Leeuw W, Wijnen J, Dreef E, Tops C, Breuning M, Bröcker-Vriends A, Vasen H, Fodde R, Morreau H. Conventional and tissue microarray immunohistochemical expression analysis of mismatch repair in hereditary colorectal tumors. Am J Pathol. 2003; 162: 469-77. PMID: 12547705

17. Van Wezel T, Lombaerts M, van Roon EH, Philippo K, Baelde HJ, Szuhai K, Cornelisse CJ, Cleton-Jansen AM. Expression analysis of candidate breast tumour suppressor genes on chromosome 16q. Breast Cancer Res. 2005; 7: R998-R1004. PMID: 16280054 